\title{
Alain Guilloux, Taiwan, Humanitarianism and Global Governance
}

\author{
London and New York: Routledge, 2009, 204 + xvii pages. \\ \$150hb, ISBN 978-0-415-46953-1
}

\section{Thomas Gold}

Received: 1 September 2010 / Accepted: 1 September 2010 /Published online: 28 September 2010

C The Author(s) 2010. This article is published with open access at Springerlink.com

Taiwan is like the late American comedian, Rodney Dangerfield, whose signature tag line was, "I don't get no respect." The leaders of Taiwan, regardless of political party, have exerted strenuous and multifaceted efforts to establish an international identity as a legitimate state, sanctified by membership in international organizations such as the United Nations. Yet time and again, although people take their money and aid, only a few stand up to the relentless pressure of the People's Republic of China (PRC) and grant Taiwan any sort of formal recognition. In this book, Alain Guilloux who has a background in international nongovernmental organizations (primarily Médecins Sans Frontières), shows how Taiwan has attempted, over the years, to participate in global governance and thereby attract positive notice and affirmation, with the hope of this eventuating in some sort of formal acknowledgement of its existence as a stand alone entity. His conclusions are bleak and scathing.

The key concept here is "governance," which refers to the "formulation and implementation of policies for collective purposes and causes." (p. 2) Governance is a complex process in which the state, market and civil society interact both domestically and globally. It comprises four elements: 1) norms and values; 2) actors, both individuals and organizations; 3) processes; and 4) outputs and outcomes. Given Taiwan's status as what he calls an "irregular state," the author hypothesizes that its leaders need to marshal all of these in order to participate in global society. Taiwan is "irregular" by nature of its unclear international diplomatic status growing out of the Cold War while at the same time being a powerhouse economy. It is also irregular in the way it combines the state, market organizations and civil society to press its case internationally. Because most other states in the world shun Taiwan as a pariah (not because it is a dictatorship or aggressive or

\section{T. Gold}

Sociology, University of California, Hat Creek, CA, USA

T. Gold $(\bowtie)$

Inter-University Program for Chinese Language Studies, Tsinghua University, Beijing, China e-mail: tbgold@berkeley.edu 
genocidal, but because China compels them to do so through various kinds of pressure), the state has to turn to companies and nongovernmental organizations (NGOs) to implement most of its international relations. This is a constant and exhausting challenge.

Guilloux selects humanitarian activity as his vehicle to explore Taiwan's efforts to be a player in the global governance game, and the bulk of the book comprises two case studies. The first case is Taiwan's efforts to join the World Health Organization, or at least, gain observer status in the World Health Assembly. This began in 1997, and actually succeeded in 2009, after the book was published. Parenthetically, this can be attributed less to any new strategy by Taiwan but as a sop by the PRC to Taiwan's new president, Ma Ying-jeou, who was markedly less hostile to China than his predecessor, Chen Shui-bian. Using the framework laid out in Chapter 2, Guilloux looks at the norms of WHO governance, the actors, processes, and outputs and outcomes regarding Taiwan's efforts to gain observer status. He shows these both in the case of the WHO itself, and as how the state in Taiwan uses them to press its case for some official status. Because Taiwan was not in the WHO, the state argued, it suffered unnecessarily from outbreaks of hoof and mouth disease, an earthquake, and SARS. This violates the WHO's norms; Taiwan should be an actor in the WHO; it uses a range of tactics to push this, including mobilizing its few diplomatic partners and its own NGOs; and it earned China's ire. In the fourth chapter, Guilloux dissects, rather mercilessly, Taiwan's actions. He argues that it is not certain that membership in the WHO would have made Taiwan's standard of living better than it already is (which is quite good), or that it would have mitigated the problems of the three crises. China's obstructions and denigration of Taiwan make the island almost irrelevant to the workings of the WHO. Guilloux suggests several ways Taiwan could improve its arguments for some status, possibly as a "sentinel" (p. 99) like Hong Kong.

The second extended case study concerns Taiwan's efforts at participating in humanitarian work. Here again, the author deploys his framework to examine the actors involved. Non-state actors, in particular the Buddhist group, Tzu-chi, have been particularly effective at home and around the world, but they generally act on their own, not taking direction from the state. Taiwan's actors follow international norms and objectives, including the UN's Millennium Development Goals. But again, Taiwan's diplomatic space, tightly circumscribed by China, severely limits its sphere of activity and recognition of its contributions. But, Guilloux notes in its quest for recognition, the Taiwan state often cuts off aid to needy countries when they succumb to pressure from China, thereby damaging its own cause.

The concluding chapter launches a blistering criticism of Taiwan's practice. Guilloux concludes that the state does not necessarily use the governance elements at its disposal fully or well. In its rather pathetic quest for diplomatic recognition, it does not make a convincing case for what difference membership in the WHO would make, is not transparent or focused in its aid programs, does not provide as much aid as it presents and pulls it at inopportune times; and most of the world does not notice what it does in any event. Taiwan gets no respect.

Guilloux's policy background is clear, as is his experience in the NGO world. Although he is sensitive to Taiwan's global predicament, he could have invested more effort in analyzing the domestic political environment, and how the 
presidencies of Lee Teng-hui and Chen Shui-bian impacted what had been longstanding international policies, provoking a new set of retaliations from Beijing and deep unhappiness in Washington, Taiwan's ultimate backer. Taiwan's status is both a relic of the Cold War and a football of China's emergence as a global power which most other nations do not dare stand up to. Selecting an outlier case, such as Taiwan, does help clarify what the actual norms of international behavior are, and the fact that they need to be maintained over time. Taiwan itself is not a model for behavior, but does serve a heuristic purpose here. I found the analytical framework useful for thinking about rule-making and maintenance more generally. Case studies in drastically different realms - environmental issues, peacekeeping, anti-terrorism, anti-piracy, intellectual property - might have provided a broader set of insights than the studies in two overlapping areas. The data come exclusively from Englishlanguage sources and interviews. It would have been interesting to hear more from Taiwan's scholarly, journalistic and political circles in their own words about what the state tries to do.

Thomas Gold is Professor of Sociology at the University of California, Berkeley, and Executive Director of the Inter-University Program for Chinese Language Studies at Tsinghua University, Beijing. His most recent book, co-edited with William Hurst, Jaeyoun Won and Li Qiang, is 'Laid-Off Workers in a Workers' State: Unemployment With Chinese Characteristics' (Palgrave McMilllan 2009). He is currently researching international NGOs' activities in China and social change in Taiwan.

Open Access This article is distributed under the terms of the Creative Commons Attribution Noncommercial License which permits any noncommercial use, distribution, and reproduction in any medium, provided the original author(s) and source are credited. 